\title{
"The Cultivation of Corn in Mayan and Modern Times": Lowell Houser's Winning Design for the Ames Mural Competition
}

\author{
BREANNE ROBERTSON
}

IN AUGUST 1935 the U.S. Treasury Department's Section of Painting and Sculpture released a formal announcement inviting artists to submit mural designs for the newly erected post office in Ames, Iowa. Unlike its predecessor, the Public Works of Art Project, the Section of Painting and Sculpture (or "the Section") was not an emergency relief program. The federal agency focused instead on aesthetic concerns in determining its public art patronage, which consisted chiefly of the construction and decoration of federal buildings. To maintain quality according to agency standards and to encourage young artists, the Section developed a selection process for commissions based on state, regional, and national competitions. The Ames mural competi-

This article is drawn from my dissertation research, which examines Lowell Houser's Evolution of Corn (1938) and other instances of U.S. artists portraying ancient Mesoamerican subject matter between the years 1933 and 1945. I would like to express my sincerest thinks to Sally M. Promey and Renée Ater for their comments and support in the preparation of this article. I would also like to acknowledge Marvin Bergman and Ginalie Swaim at the State Historical Society of Iowa, Dennis Wendell at the Ames Historical Society, Tanya Zanish-Belcher at Iowa State University, Gene Morris at the National Archives II, and Matthew Sams and Marie Kroeger at the Art Institute of Chicago for their assistance in consulting unpublished materials on Lowell Houser.

THE ANNALS OF IOWA 70 (Winter 2011). (C) The State Historical Society of Iowa, 2011. 
tion was one such competition, held to decide which regional artist would decorate the new post office. The parameters of the design competition stipulated that eligible artists must reside in Iowa or adjacent states and that subject matter for the mural be related to the local activities and history of Ames. Specifically, the announcement identified the industry, pursuits, or scenery of Iowa; historical events of local significance; and the postal service as appropriate subject matter for the public mural. ${ }^{1}$

As a general guideline, the Section designated 1 percent of construction costs for the decoration of new federal buildings. In Ames, the mural competition promised the winning artist a government contract in the amount of $\$ 1,300$ to cover costs for the production and installation of the post office mural; other worthy submissions would receive smaller commissions in other Iowa towns. This monetary award was not insignificant; $\$ 1,300$ in 1935 translates to roughly $\$ 20,700$ in 2010 . $^{2}$ For regional artists, many of whom struggled financially in the hard economic climate of the Great Depression, such an opportunity - to earn a steady paycheck and to work under the aegis of the federal government on a public building — was a highly attractive prospect.

Twenty-seven artists participated in the Ames mural competition. Although the formal training, professional experience, and natural talent of the artists varied, Superintendent Edward B. Rowan of the Section of Painting and Sculpture nonetheless expressed pleasure with the breadth and quality of mural entries. In a letter to Des Moines art librarian and competition juror Louise Orwig, he wrote, "Some good work is included [among the entries] and I believe it will be possible to award not only the Ames commission but also the other three post offices listed in your announcement form. ${ }^{3}$

1. Formal announcement from the U.S. Treasury Department's Section of Painting and Sculpture regarding the Ames mural competition in the folder "Iowa Competitions," Case Files for Embellishment of Federal Buildings, Records of the Public Buildings Service, RG 121, entry 133, box 28, National Archives, College Park, Maryland (hereafter cited by Record Group, entry, and box number only, e.g., RG 121, entry 133, box 28).

2. This information is based on the CPI Inflation Calculator, Bureau of Labor Statistics, U.S. Department of Labor, at http://data.bls.gov/cgi-bin/cpicalc.pl.

3. Edward B. Rowan to Louise Orwig, 11/16/1935, RG 121, entry 133, box 28. 


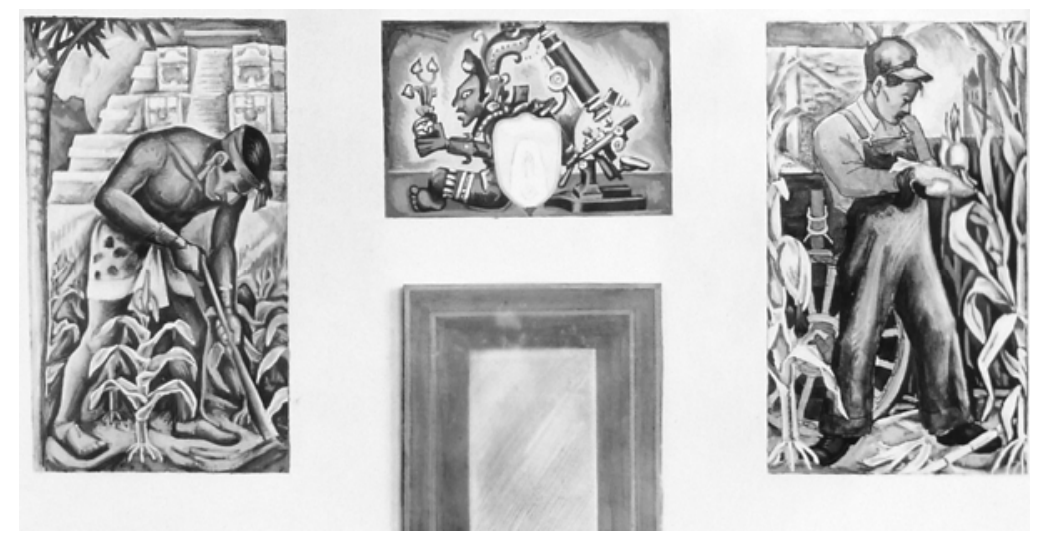

Figure 1. Lowell Houser, Preliminary Sketch, 1935. Courtesy National Archives II, College Park, photo no. 121-MS-1HOUS-20.

That fall the Section awarded the Ames Post Office mural contract to Lowell Houser. Richard Haines, R. F. Gates, and Richard B. Tabor received smaller mural commissions for post office buildings in Cresco, Harlan, and Independence, respectively. Houser's winning design included two vertically oriented rectangular pendant panels flanking the Ames postmaster's office door (fig. 1). The left image portrays a scene from antiquity, a Mayan Indian tending maize, while the right panel depicts its modern equivalent, a contemporary Iowa farmer harvesting ripe ears of corn. A smaller, central square panel unites these two compositionally and thematically with a decorative heraldic design composed of an indigenous deity, a seed kernel, and a scientific microscope. The success of Houser's design seems to have eclipsed any consideration of its historical inaccuracy, particularly with regard to the inclusion of a Mexican Indian in a mural dedicated to the local history and culture of Ames, Iowa. ${ }^{4}$

The territory now known as Iowa possesses a rich and diverse history with regard to American Indian civilizations. A

4. Houser's career as a whole remains understudied and relatively unknown to art historians and critics. The only sustained investigations of Houser's mural to date and, as such, an essential touchstone for this current study, are Mary L. Meixner, "Lowell Houser and the Genesis of a Mural," and idem, "The Ames Corn Mural," both in The Palimpsest 66 (1985), 2-29. 
broad range of North American tribes - ancient Mound Builders, Sioux, Algonquians, Sauk, Meskwaki, Ioway — inhabited the grassy plains and lush river banks of the future state. Yet at no point in its long history did Iowa serve as a homeland to the Mayan Indians. Why, then, did Houser choose to include a Mayan Indian in his composition? I posit an explanation for this artistic decision by examining the myriad sources of inspiration for his mural design and by analyzing the circumstances of the Ames mural competition. By adhering to traditional notions of history painting and by displaying firsthand knowledge of Mexican culture in both subject and style, Houser crafted a mural design in which he asserted a continuity not only of agricultural practice in the Americas from antiquity to the present but of distinguished art-making as well. His choice of Mayan subject matter represents the concentrated effort of an artist to distinguish his work among a strong pool of applicants in the Ames mural competition. In so doing, Houser skillfully demonstrated a technical and thematic expertise in his mural sketch that fulfilled the lofty aims of the federal selection committee and ultimately won for him the competition.

BORN IN CHICAGO in 1902, Lowell Houser moved with his family to Ames, Iowa, when he was seven years old. The son of a streetcar conductor, he spent the remainder of his youth in Ames and graduated from Ames High School in 1921. He attended Iowa State College for one quarter, but withdrew at the end of the term to pursue a career in painting.

In 1922 Houser began his formal training at the Art Institute of Chicago, where he studied painting, mural design, and illustration. His attendance at the conservative art school instilled in him conventional ideas about the didactic function and elevated status of history painting, which ranked at the top of the hierarchy of academic genres. In its most traditional form, history painting depicted historical or mythological events to teach moral or civic virtues. Artists typically selected noble yet dramatic narrative incidents from textual accounts and made a serious effort to incorporate descriptive details to bolster credibility and a perception of truth. Lofty in tone and large in scale, history paintings presented viewers with an elegant representa- 
tion of past events and an exemplary model for future change. Such images, successfully executed, possessed sufficient rhetorical agency to inspire higher thoughts, proper modes of conduct, or patriotic feelings in the public. ${ }^{5}$ Among Houser's teachers were the noted Chicago artists Louis Grell, Albert H. Krehbiel, and Harry I. Stickroth. ${ }^{6}$ Under their tutelage, Houser learned the necessary components of history painting - knowledge that would serve him well in the Ames mural competition 12 years later.

At the Art Institute of Chicago, Houser met and became close friends with fellow art student Everett Gee Jackson, who convinced him that Mexico was the ideal place to pursue his artistic ambitions. The following year, the two men embarked on a series of extended trips to Mexico. Houser's exposure to Mexican art, both ancient and modern, coupled with the personal connections he would make during his sojourn abroad, had a profound and lasting influence on his art production, particularly with regard to style and subject matter.

In June 1923 Houser and Jackson drove from Jackson's boyhood home in Mexia, Texas, to the Sabinas Mountains in Mexico's border state of Coahuila. ${ }^{7}$ Although their initial goal was to live among the Kickapoo Indians, the two artists struggled to gain favor with the native inhabitants of the sparsely populated region. As art historian James Oles succinctly put it, "the Indians had little interest in hosting these seekers of the "primitive.' "'8 After a few weeks of exploring and sketching, the pair returned to Texas and quickly devised a plan to make a second trip to Mexico in the fall. This time, they would venture deep into the interior of the country in search of preindustrial countryside and picturesque peasants.

5. My discussion and terminology with regard to history painting relies on the definition of the genre and its component parts in Patricia M. Burnham and Lucretia Hoover Giese, eds., Redefining American History Painting (New York, 1995).

6. The Art Institute of Chicago, School Catalogue, List of Instructors and Lecturers, 1922-1923, photocopy provided by Matthew Sams, Assistant Director, Registration and Records, and archives volunteer Marie Kroeger.

7. D. Scott Atkinson, Everett Gee Jackson: San Diego Modern, 1920-1935 (San Diego, 2007), 16.

8. James Oles, South of the Border: Mexico in the American Imagination, 1914-1917 (Washington, DC, 1993), 79. 
In September Jackson and Houser boarded a train for Guadalajara; soon the two artists pushed beyond the bustling colonial city and settled in Chapala. Jackson later recalled their delight at the pristine village, as yet untouched by modern industry: "Lowelito [Jackson's nickname for Houser] and I were speechless at what we had found." He explained that "Chapala in 1923 was not at all the way it is today," but remained still a "visual world of magic: bright sunshine and blue shadows up and down the streets, red tile roofs and roofs made of yellow thatch, banana trees waving above the red tile roofs, bougainvillea of brilliant color hanging over old walls, the gray expanse of the lake, and a sky in which floated mountainous clouds." The two men were so inspired by this "overlooked paradise," Jackson wrote, that they routinely lost track of time while drawing and painting their new environment. ${ }^{9}$

During this productive period in Chapala, Houser met Anita Brenner, who, like Jackson, played a significant role in determining the course of his career. A Mexican citizen whose family had moved to Texas during the Mexican Revolution (1910-1917), Brenner returned to Mexico City in 1923, when she was 18 years old. Brenner's activities as an anthropologist, political writer, and art critic brought her into contact with nearly every artist, intellectual, and journalist in the capital, including the Mexican muralists. Reflecting on her intimate connection to Mexico's avantgarde artists, Brenner wrote in her journal, "I am proud when I think that the best of Mexico [are] my closest friends," mentioning specifically José Clemente Orozco, Jean Charlot, and Francisco Goitia. ${ }^{10}$ During a chance meeting in Chapala, Brenner suggested to Houser that he join the archaeological expedition of the Carnegie Institution of Washington, which had recently signed a contract with Mexico to excavate, repair, and restore the ruins at Chichen Itza. Houser expressed interest in the project and, to his great surprise, soon received an offer to become an "artist in residence" at the ancient site. ${ }^{11}$

9. Everett Gee Jackson, Burros and Paintbrushes: A Mexican Adventure (College Station, TX, 1985), 5.

10. Susannah Glusker, Anita Brenner: A Mind of Her Own (Austin, TX, 1998), 46.

11. Jackson, Burros and Paintbrushes, 107. Brenner was so impressed with Houser's talent that she had orchestrated this opportunity for her new American friend. 


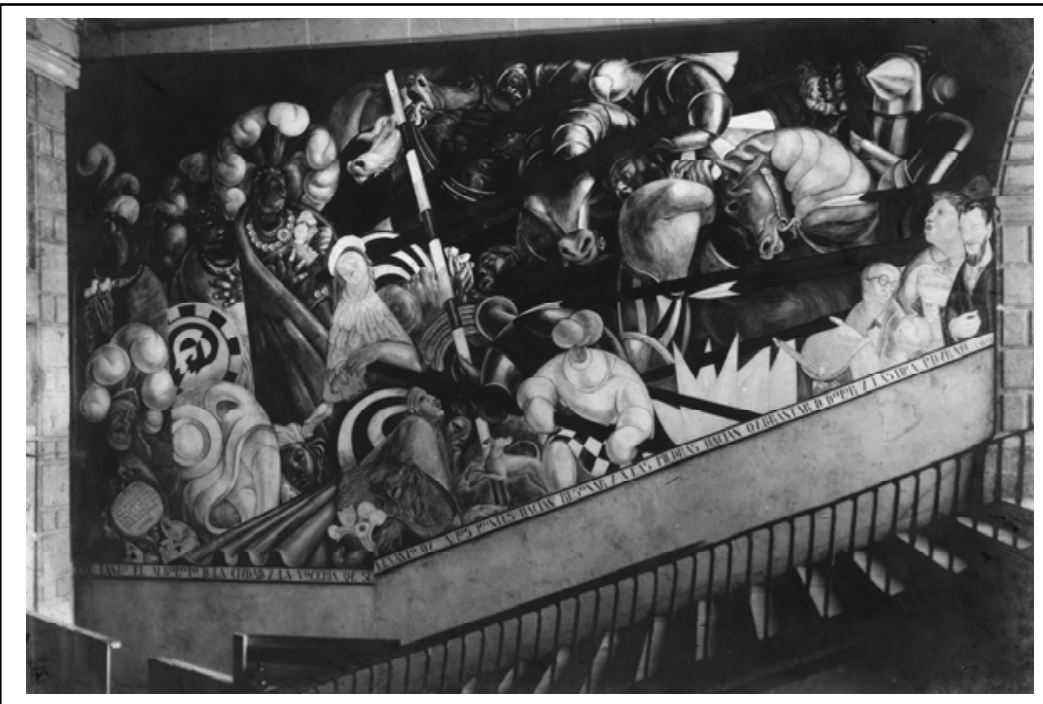

Figure 2. Jean Charlot, The Massacre in the Main Temple (1922-1923). Fresco, 14' x 26', National Preparatory School, Mexico City. Photograph courtesy Jean Charlot Collection, University of Hawaii at Manoa Libraries.

In preparation for his departure for the Yucatan, Houser relocated to Coyoacan near Mexico City in the fall of 1926. There the American became acquainted with many members of Brenner's distinguished social circle, including Jean Charlot. Born in Paris to a Mexican mother and a French father, Charlot had arrived in Mexico City in 1921 and quickly established himself as a member of the cultural avant-garde, becoming close friends with Fernando Leal and Diego Rivera. In 1923 he assisted Rivera in painting Creation (1923) at the National Preparatory School in Mexico City. Charlot also produced a mural of his own design for the school. Titled The Massacre in the Main Temple (1922-1923), the mural portrays the dramatic defeat of the Aztecs during the Spanish Conquest (fig. 2). ${ }^{12}$

In her book Idols Behind Altars (1929), Brenner described Houser as an American artist who had "gone Mexican" and whose art drew inspiration from "Mexican scene and popular design." After meeting Brenner only briefly, Houser likewise held her in great esteem, admiring both her intellect and her kindness.

12. This mural has also appeared in publications under the title The Fall of Tenochtitlan. Jean Charlot states in his essay "Jean Charlot's First Mural: The 
Houser was already well versed in the activities of the Mexican muralists prior to meeting Charlot. In 1925 Houser and Jackson had made a brief visit to Mexico City to view the public murals. Jackson later recalled in his autobiography his lukewarm response to those modern frescoes, stating that the paintings seemed to him "like the funny-paper drawings, only much more refined." Houser, by contrast, found them "very exciting." Although Jackson did not identify which works of art they viewed, the two Americans likely visited the National Preparatory School to see the well-publicized murals of Rivera, Charlot, and others. It must have been personally significant for Houser when, the following year, he had the opportunity not only to befriend Charlot but to have the muralist critique his paintings. Houser naturally placed much stock in the experienced muralist's opinions. Jackson recalled in his autobiography how he and Houser both "regarded Charlot with unfaltering respect" and suspected that his advice "just might indicate the right direction" for their art. ${ }^{13}$

Charlot continued to exert a strong influence on Houser's artistic development over the next two years as the pair worked side by side as field artists at Chichen Itza. Excavations at the site had begun in 1924 under the direction of American archaeologist Sylvanus Griswold Morley and were well under way when Houser joined the project three seasons later. Houser, Charlot, and another field artist, Ann Axtell Morris, created scale drawings of ancient Mayan stelae and mural paintings. From Charlot, Houser gained an appreciation for Mayan art and culture as a noble example of antiquity. "When I came I thought Maya art was primitive," wrote Houser in a 1927 letter to Jackson; "now I think it is the most civilized that I know. In the collection of a rich family in Merida there is a Maya vase which dates probably to 400 or 600 A.D. in the period of the Old Empire of Guatemala, the earliest period by far, and the most perfect." ${ }^{14}$ Houser also adopted Charlot's view that ancient Mesoamerican civilizations

Massacre in the Main Temple" that this second appellation is erroneous. See Jean Charlot Collection, University of Hawaii at Manoa Libraries, Honolulu, Hawaii. 13. Jackson, Burros and Paintbrushes, 40.

14. Mary L. Meixner, "Lowell Houser's Poetic Glass Mural in Des Moines," Palimpsest 73 (1992), 34. 
offered fitting subject matter for public art, as the elder artist had demonstrated in The Massacre in the Main Temple.

Upon his return to the United States in 1929, Houser must have noted that a pervading interest in Mexican art and culture had swept the nation. In the art world, exhibitions of Mexican art surged in number during the 1920s and 1930s. Those shows, which ranged in focus from ancient artifacts and plaster reconstructions of Mayan temples to Mexican folk art and modern painting, presented the American public with ample evidence regarding Mexico's rich artistic traditions. In architecture, the Mayan Revival style grew rapidly in popularity and spread throughout the country. American tourism to Mexico and publications about Mexico, ranging from non-fiction to children's books, also increased significantly. ${ }^{15}$ If Houser's associations and experiences in Mexico had not already convinced him of the aesthetic value of ancient Mesoamerican civilizations, his decision to feature a Mayan figure in his competition design may have resulted from this widespread popular fascination with Mexican art and culture.

Notably, several pre-Columbian scholars served as consultants to architects and industrial designers seeking to incorporate authentic motifs into their Mayan Revival designs. A leading expert in Mesoamerican archaeology and Mayan hieroglyphics, Sylvanus Morley, acted as consultant to architect Albert Kahn during the construction of the Fisher Theater (1928) in Detroit, Michigan (fig. 3). Since Morley was also the acting director of the Carnegie Institution of Washington at this time, it is not surprising that many of the decorative motifs at the theater derive directly from the Mayan sculptures, tiles, and murals uncovered

15. Helen Delpar, The Enormous Vogue of Things Mexican: Cultural Relations Between the United States and Mexico, 1920-1935 (Tuscaloosa, AL, 1992), 16, 55-58. Mexico accounted for only 4.6 percent of American expenditures for foreign travel in 1923. By 1930 that percentage had risen to 8.2 percent, and in 1933 American expenditure in Mexico was 16.7 percent of all foreign travel. The number of books about Mexico reviewed in Book Review Digest between 1920 and 1927 was 35; that number increased to 65 for the years 1928 to 1935 . Delpar tallied these figures based on the books listed under the categories Mexico and Mexico City and the subcategories Antiquities, Description and Travel, Foreign Relations, History, Politics, Government, Social Life and Customs. She notes that the years indicate when the reviews appeared in print, not necessarily when the books were published. 


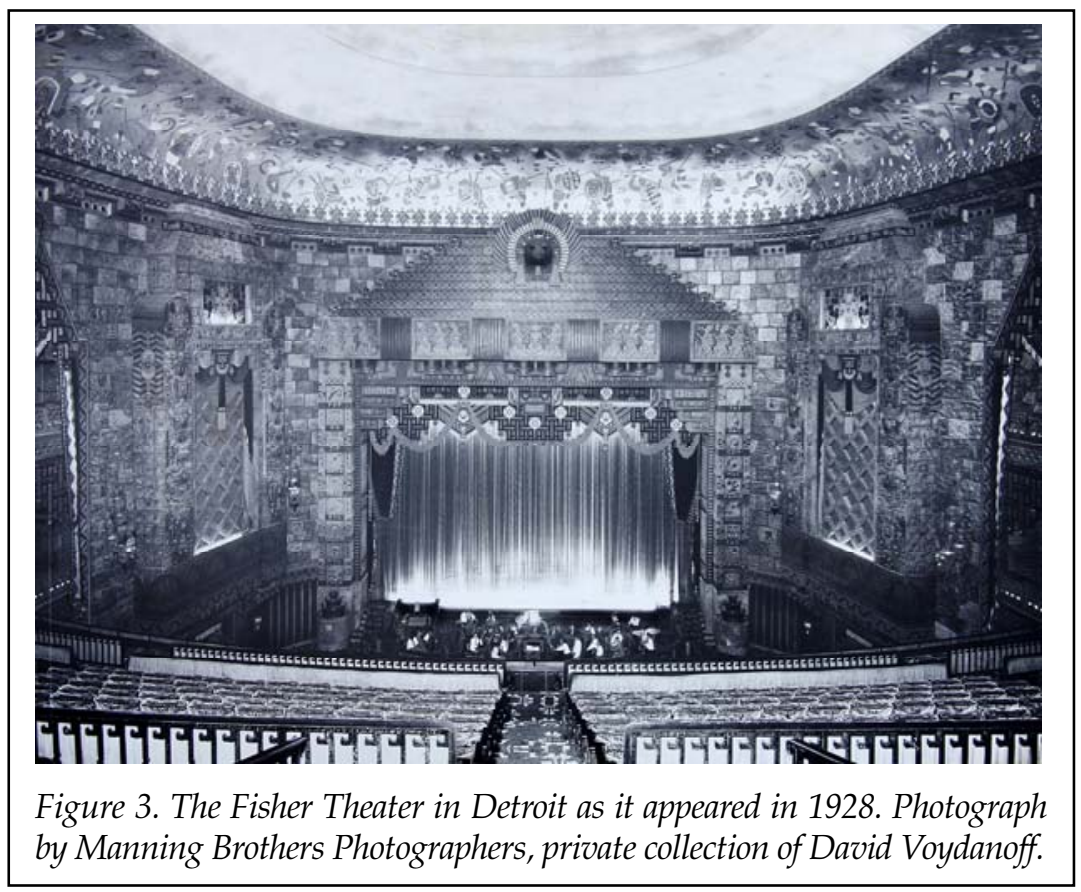

at Chichen Itza. Houser, who worked alongside Morley at the Carnegie Institution of Washington's archaeological site for two seasons, must have known of his supervisor's activities and perhaps even discussed the topic with him on occasion.

Mexico's modern muralists themselves garnered fame and popularity exhibiting and working in the United States. Houser, who met muralists Jean Charlot and José Clemente Orozco during his sojourn in Mexico, surely took note of their activities upon his return home. Reflecting the keen interest many American artists took in the Mexican muralists, Thomas Hart Benton recalled years later, "I saw in the Mexican effort a profound and much-needed redirection of art toward its ancient humanistic functions. The Mexican concern with publicly significant meanings and with the pageant of Mexican life corresponded perfectly with what I had in mind for art in the United States. I also looked with envy on the opportunities given Mexican painters for public mural work."16 Between 1930 and 1934, Rivera and

16. Delpar, The Enormous Vogue of Things Mexican, 128. 
Orozco executed major mural commissions across the nation, including the controversial and highly publicized fresco panels at Rockefeller Center and Dartmouth College. In addition, American Ambassador to Mexico Dwight Morrow used his connections with the Carnegie Corporation to organize a large exhibition of Mexican art at the Metropolitan Museum in New York City. More than 25,000 visitors attended the exhibition Art in Mexico, which featured the work of 24 Mexican painters, including Orozco, Rivera, and Charlot. From New York, the exhibition traveled to 13 other cities in the United States, reaching roughly 450,000 people. ${ }^{17}$

By the 1930s, the Mexican example of mural painting not only bolstered arguments for U.S. government sponsorship of public art but offered a model, both technically and thematically, for American artists to emulate. George Biddle, an old schoolmate of Franklin D. Roosevelt, employed this precise line of reasoning in his appeal to the president in support of a federal art program. On May 9, 1933, he wrote,

The Mexican artists have produced the greatest national school of mural painting since the Italian Renaissance. Diego Rivera tells me that it was only possible because Obregon allowed Mexican artists to work at plumbers' wages in order to express on the walls of the government buildings the social ideals of the Mexican revolution.

The younger artists of America are conscious as they have never been of the social revolution that our country and civilization are going through; and they would be eager to express these ideals in a permanent art form if they were given the government's cooperation. They would be contributing to and expressing in living monuments the social ideals that you are struggling to achieve. ${ }^{18}$

Biddle's encouragement worked. That winter the U.S. government initiated the Public Works of Art Project (PWAP), the first in a series of art patronage programs established under the New Deal. Houser was among the earliest American artists to receive government support in 1934, when he assisted Grant Wood on the ambitious nine-panel mural cycle, When Tillage Begins, Other Arts Follow, at Iowa State College. Acknowledging the Mexican

17. Ibid., $144-45$.

18. George Biddle, George Biddle: An American Artist's Story (Boston, 1939), 268. 
mural program's important role in providing a model for the U.S. government to follow, PWAP Director Edward Bruce doubted "whether the impetus to employ the more liberal painters in America would ever have made the progress that it has without the great awakening which was brought to us from Mexico." ${ }^{19}$

The paintings of Mexican muralists Rivera and Orozco left a strong impression on many American artists in the 1930s. Edward Laning, for example, watched Rivera paint at Rockefeller Center "night after night" because he wanted "to learn about fresco painting from someone who knew." And Harry Donald Jones paid explicit homage to Orozco in his 1937 mural cycle at the federal courthouse in Cedar Rapids, Iowa, by illustrating the Mexican artist at work on his murals for Dartmouth College. ${ }^{20}$

Houser's approach to mural painting also closely followed Mexican precedents, since his introduction to public mural art occurred during his travels south of the border. He developed an early yet enduring enthusiasm for Mexican style and subject matter in his art. Throughout his career Houser demonstrated a sustained interest in and strong conviction for ancient Mayan culture in particular. In addition to the Ames mural, he published Mexican-style woodcuts in Dial Magazine and illustrated several children's stories on pre-Columbian themes, including Alida Malkus's Newbery Award-winning book, The Dark Star of Itza: The Story of a Pagan Princess (1931; fig. 4). In 1938 he again proposed a Mayan Indian as the primary subject for a glass mural at the Bankers Life building in Des Moines. When his clients insisted that he modify his design using a North American Indian instead, Houser complied with regret, stating, "I am a little sorry to move out of the Maya field. . . . It is so darned rich and so well suited to the round corners of your building., ${ }^{21}$

19. Edward Bruce and Forbes Watson, Art in Federal Buildings: An Illustrated Record of the Treasury Department's New Program in Painting and Sculpture (Washington, DC, 1936), 1:23. See also Lea Rosson DeLong, When Tillage Begins, Other Arts Follow: Grant Wood and Christian Petersen Murals (Ames, 2006).

20. Edward Laning, "The New Deal Mural Projects," in The New Deal Art Projects: An Anthology of Memoirs, ed. Francis V. O'Connor (Washington, DC, 1972), 79-114. Other artists who worked on the Cedar Rapids Federal Courthouse mural cycle were Francis R. White, Don Glasell, and Everett Jeffrey. I thank Gregg R. Narber for bringing this mural to my attention.

21. Meixner, "Houser's Poetic Glass Mural," 34. 


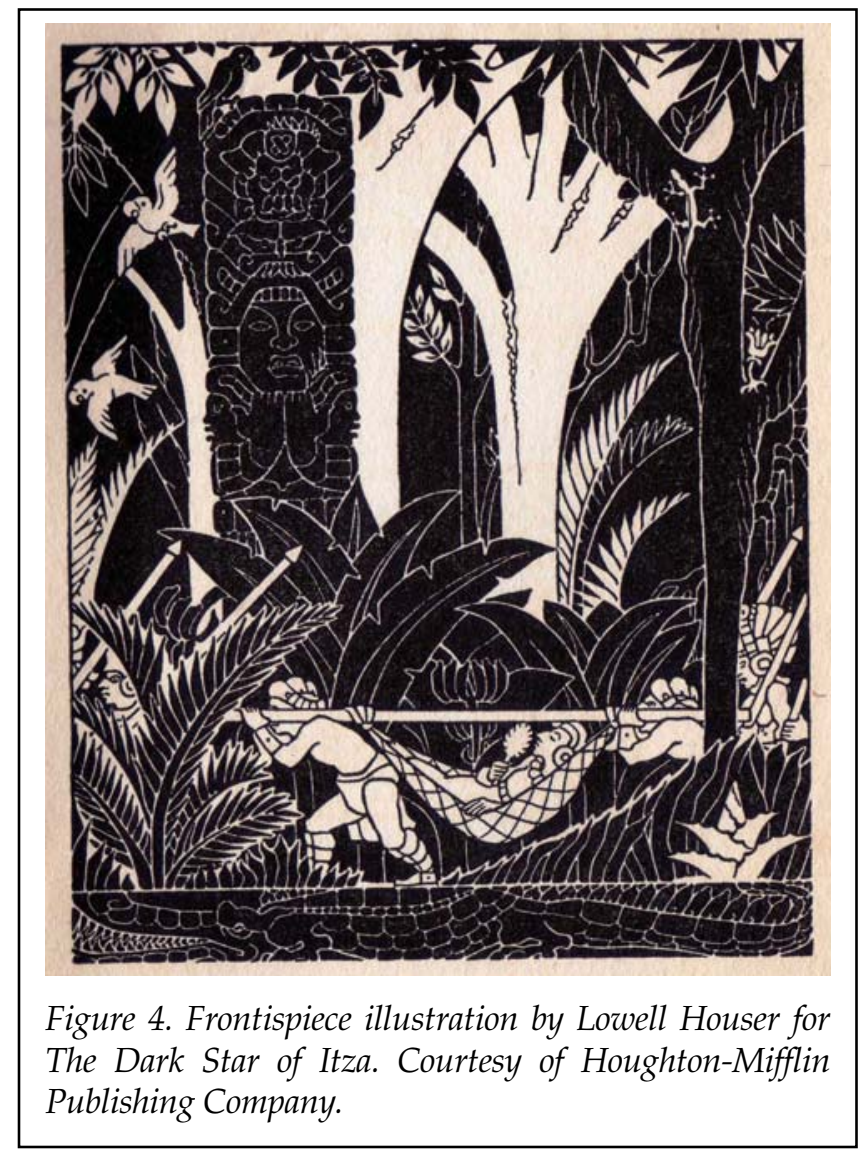

GIVEN THE RECENT POPULARITY of Mexican art and culture in the United States at the time of the Ames mural competition, Houser naturally believed that a mural design incorporating Mesoamerican history would appeal to art officials on the selection committee. Unlike other government-sponsored projects supporting public art, such as the Treasury Relief Art Project and the Works Progress Administration, the Section of Painting and Sculpture did not require artists to be eligible for financial relief. Quality, instead, was the primary criterion for determining whether an artist received a commission. This emphasis on artistic merit reflected the Treasury Department's stated goal of acquiring "the best available American art" and making it available throughout the country so that it might up- 
lift public morale during the lean Depression years. ${ }^{22}$ Edward Bruce explained,

Our objective should be to enrich the lives of all our people by making things of the spirit, the creation of beauty part of their daily lives, by giving them new hopes and sources of interest to fill their leisure, by eradicating the ugliness of their surroundings, by building with a sense of beauty as well as mere utility, and by fostering all the simple pleasures of life which are not important in terms of dollars spent but are immensely important in terms of a higher standard of living. ${ }^{23}$

Beauty was not the only characteristic necessary for a successful design submission, however. In their endeavor to make art available to all Americans, art project officials adhered to a traditional academic belief in the civilizing capacity and educational benefits of fine art. "Good contemporary art," observed Forbes Watson, "spread throughout the country and always visible to the inhabitants of town and hamlet and city, is almost certainly destined to have results in educating the artist and the layman." ${ }^{24}$ Paintings portraying religious, mythological, literary, historical, and allegorical subject matter most easily carried a moralizing message or intellectual theme, so the genre of history painting (which might include all of these) was generally the preferred mode in art academies for creating didactic works of art.

Adhering to this conventional view of history painting, the Section directed potential applicants in the Ames competition to compose a mural design centered on themes of "the Post; local history, past or present; local industry, pursuits, or scenery." ${ }^{25}$ The government call for paintings of local relevance was not unique to the Ames mural competition; it reflected broader institutional notions of what constituted suitable subject matter for public art. Art project officials justified their preference for local subject matter, claiming that "a work of art carries more

22. Bruce and Watson, Art in Federal Buildings, 1:xii.

23. Memorandum in support of project to employ artists under Emergency Relief Appropriation Act of 1935, enclosed in letter from Edward Bruce to Franklin D. Roosevelt, 5/1/1935, RG 69.5.2, box 432.

24. Bruce and Watson, Art in Federal Buildings, 1:23.

25. Formal announcement for the Ames mural competition, RG 121, entry 133, box 28 . 
meaning for the people when it deals with familiar subject matter and reflects their local interests, aspirations, and activities." ${ }^{26}$

Art officials envisioned the post office as an ideal site for public art. Located in large cities and small rural towns across the nation, these public buildings served as social centers for the community. Almost everyone visited their local post office regularly, so the art installed there would reach the greatest number of people and, it was hoped, inspire in them lofty thoughts about their community and its past. ${ }^{27}$ Forbes Watson stressed the educational mission of the government-sponsored mural program when he posed the question: "When the farmer, the laborer, the village children and the shopkeepers go to the nearest Post Office and see there, for example, a distinguished work of contemporary art depicting the main activities, or some notable events in the history of the town, is it too exaggerated to suggest that their interest will be increased and their imagination stirred?" 28

To distinguish his work in this competitive New Deal environment, Houser needed not only to demonstrate to the federal selection committee a capacity for technical excellence, but also an original thematic conception appropriate to the elevated function assigned to public art. Fortunately, the artist's formal academic training and subsequent travel to Mexico equipped him with the skills and breadth of knowledge necessary to meet this challenge. According to Superintendent Edward B. Rowan, Houser's mural sketch stood out for its "outstanding intelligence of the conception" and "real unity of idea." ${ }^{29}$ In other words, his composition presented unusual and innovative subject matter in a manner perfectly suited to the aims of public art.

Few artists in the Ames mural competition dared to stray from the recommended themes of local history, local industry, and the postal service. Despite the claim in the formal announcement that these subjects "may be interpreted freely" and that, above all else, the jury desired "as distinguished and vital a con-

26. Section of Fine Arts, "Exhibition of Photographs and Sculpture," RG 121, entry 137, box 3 .

27. Marlene Park and Gerald E. Markowitz, New Deal for Art (Utica, NY, 1977), 37.

28. Bruce and Watson, Art in Federal Buildings, 1:23-24.

29. Edward B. Rowan to Lowell Houser, 11/21/1935, RG 121, entry 133, box 28. 


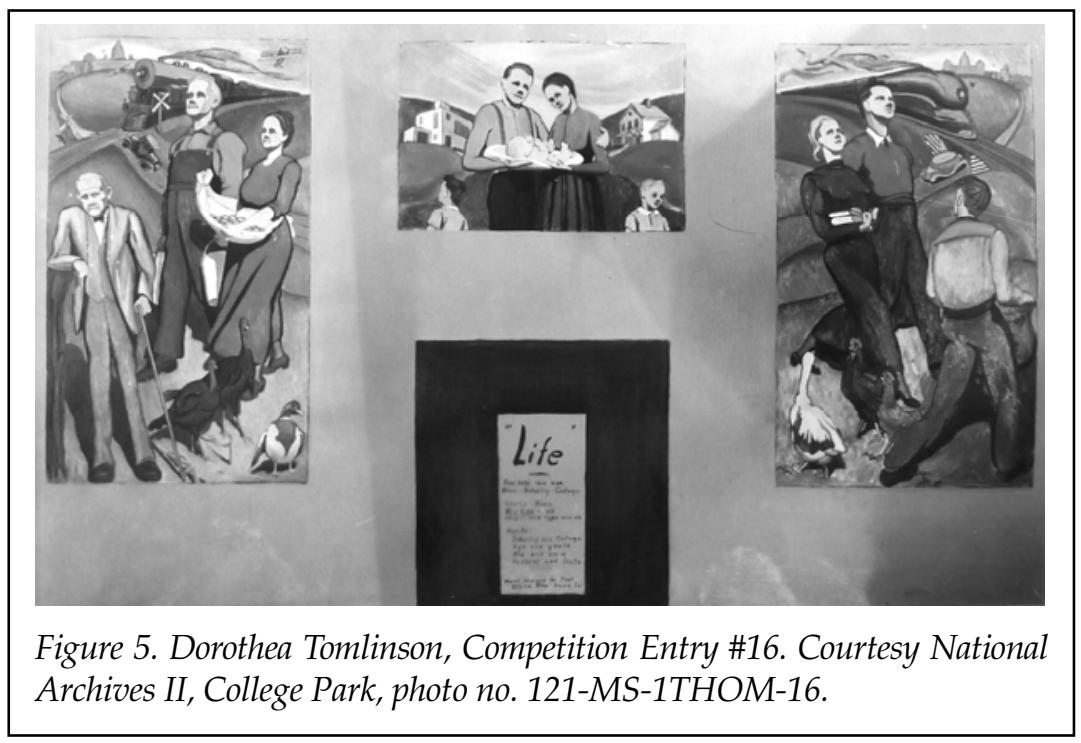

ception as possible," the majority of design entries for the Ames mural competition presented viewers with idyllic scenes of Iowa farm life or grand tributes to pioneer settlers. ${ }^{30}$ Dorothea Tomlinson, for example, in her competition entry chose to depict three stages in the lifecycle of Iowa residents (fig. 5). Divided into three panels, the mural design presents a trio of collegebound students, a married couple with young children, and an older set of retirement-aged individuals. A continuous rolling landscape unites the three scenes, and accoutrements such as books, fresh eggs and milk, and small children attest to the abundant prosperity of Iowa pursuits, be they intellectual, agricultural, or interpersonal. Robert Allaway, Frank Vernall, E. L. Allen, Vernan Etler, Mignon Wray Lynch, Harry Donald Jones, Felix Summers, and Rea James similarly portrayed Iowa in their competition entries as an idealized, pastoral paradise of virtuous farmers, handsome livestock, and fertile lands.

Houser, by contrast, devised an original theme for the Ames mural competition: "The Cultivation of Corn in Mayan and Modern Times." Clearly divided into three distinct sections,

30. Formal announcement for the Ames mural competition, RG 121, entry 133, box 28 . 


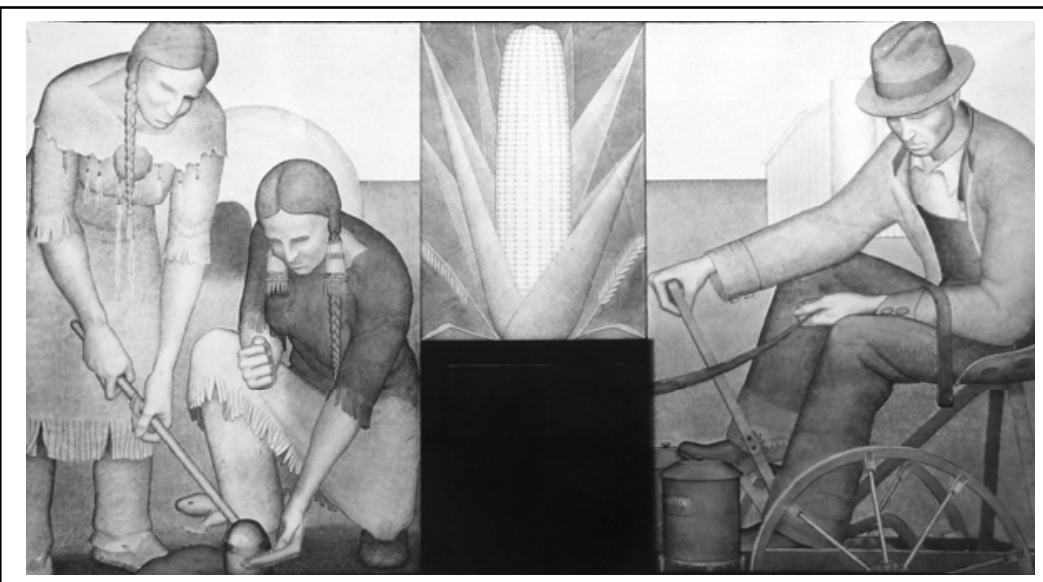

Figure 6. E. L. Allen, Competition Entry \#15. Courtesy National Archives II, College Park, photo no. 121-MS-1ALLE-15.

Houser's submission differs little in conception from the final mural installed two-and-a-half years later. In the left panel of the sketch, a Mayan Indian leans forward to push a rudimentary tool into the fertile soil of a field of young corn, while, in the right panel, a modern Iowa farmer harvests a ripe ear of corn amid the mature stalks surrounding him. A wagon waiting to be filled with the harvest appears directly behind the Iowa farmer, who does not mirror the bent Mayan figure in posture but rather stands fully upright to perform his task. A scientific microscope and Mayan maize god appear in the central panel behind an oversized kernel of corn. An overall formal emphasis on vertical elements such as the palm tree, erect figures, and tall cornstalks dominates the composition (fig. 1).

Houser was not alone in his decision to highlight Iowa agriculture, nor was he the only artist to incorporate Native Americans in his mural design. Ernest Freed, Elizabeth Lochrie, and others featured North American Indians in their pictorial renderings of pioneer settlers and westward expansion. David Warren Sexton and E. L. Allen, like Houser, even combined the themes of agriculture and indigenous history in their representations of American Indians growing corn. Allen's mural design, in particular, bears a resemblance to Houser's finished mural, as it was installed at the Ames post office (figs. 6 and 7). 


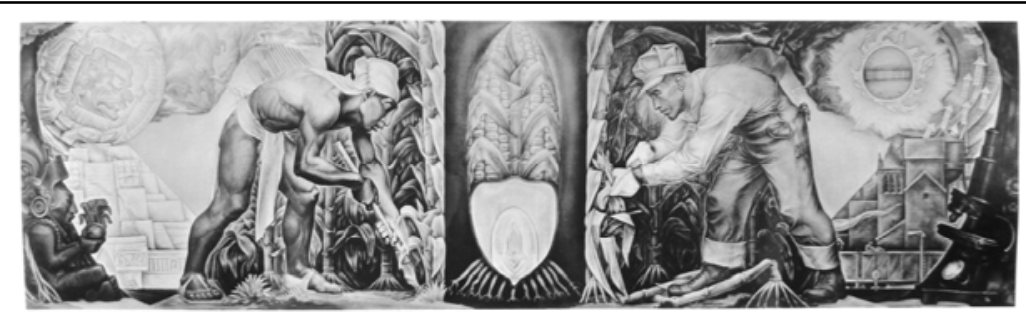

Figure 7. Lowell Houser, The Evolution of Corn, 1938. Oil on canvas, Ames Post Office, Ames, Iowa. Courtesy Section of Fine Arts, Public Buildings Administration, National Archives II, College Park, photo no. 121-GA-25HOUS-2295.

In both works, two scenes of corn cultivation, one ancient and one modern, flank a central partition depicting an oversized ear of corn. Conceptually both works construct a visual argument claiming a seamless agricultural lineage in which the modern Iowa farmer descended, culturally at least, from an indigenous source. What distinguished Houser's composition from Allen's design and others in the Ames mural competition is the Mesoamerican identity of his Indian figure.

HOUSER eventually won the Ames mural competition, but his mural design did not fare well in the first round of jury deliberations. On November 2, 1935, an appointed local committee consisting of cosmetics magnate and art collector Carl Weeks, art librarian Louise Orwig, and architect John Normile met in Des Moines to perform a preliminary evaluation of the competition entries. Their task was to determine the relative aesthetic merit of contest submissions using two major criteria: technical execution and subject. The top designs were those that "best solve[d] the problems of scale and color in relation to the architecture" and that were "most suitable in theme and subject matter." ${ }^{31}$ To ensure a fair assessment of their work, artists participated in the contest anonymously, identifying their designs by number only.

31. The Corcoran Gallery of Art, Exhibition of Painting and Sculpture Designed for Federal Buildings (Washington, DC, 1939), 1, in Still Photographs, RG 121-CGA, box 1 . 


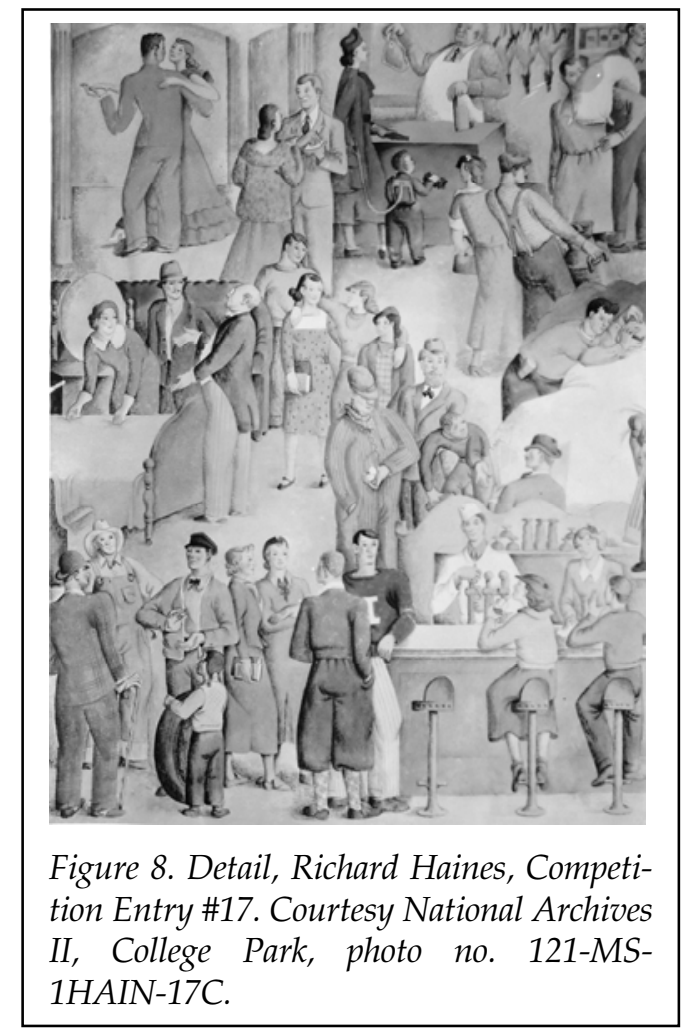

On November 9, Orwig notified Superintendent Rowan that the Iowa committee had selected entries \#17, 12, 10, 22, and 16, designs belonging to Richard Haines, Robert Allaway, Ernest Freed, Felix Summers, and Dorothea Tomlinson. Houser's entry was not among the finalists. Instead, the local jury exhibited a strong preference for scenes of contemporary farming and smalltown life. Richard Haines's mural submission, for example, consists of three rectangular panels all teeming with vibrant scenes of daily Iowa activities (fig. 8). Haines assembled ordinary locations and events - furniture shopping, dancing, socializing at a soda shop, buying meat from the local butcher - and elevated them to the status of fine art. Remarking on Haines's design in a letter to Superintendent Rowan, Carl Weeks enthusiastically proclaimed, "Our first choice is a honey." ${ }^{32}$

32. Carl Weeks to Edward Rowan, 11/7/1935, RG 121, entry 133, box 28. 
Louise Orwig, however, soon expressed reservations about the artworks she and the other Iowa committee members had endorsed. In a second letter to Rowan she admitted, "I feel that our judgment was hasty after living with the designs." She assured the Section official that anonymity within the competition was not breached and that their decision was unbiased. She then recommended Houser for the commission, stating, "I consider Lowell Houser outstanding in ability and would consider it a 'coup' for the Treasury Dep't if they would use him for designing the Ames mural. I believe that he would make something of great value to the community in which he lives and is interested. I really hope that it will be so." Superintendent Rowan judiciously replied that he was glad to know the competition remained absolutely anonymous and that he hoped "a fine piece of work will result." ${ }^{33}$

Mural sketches for the Ames mural competition arrived in Washington, D.C., for final review by mid-November. After several days of deliberation and study, a jury composed of representatives from the Section and from the Supervising Architect's office agreed to overturn the decision of the Iowa committee and to award the Ames Post Office mural commission to Lowell Houser. Superintendent Rowan, recognizing the sensitivity of the situation, drafted a lengthy explanation for Carl Weeks defending the unexpected competition result. On Haines's mural composition, he wrote,

The Section admired the spirit and observation in the Haines designs and appreciated the wide local interest they would have. Agreeing largely, if not completely, with your estimate of Haines' work, the Section has awarded Haines the mural in Cresco, Iowa, Post Office, on the basis of Design \#6 [fig. 9]. The Section preferred these designs to his others because of their greater organization. He seemed more successful in simplifying his material for the smaller sized panels than in letting it run all over the wall. In preparing his design for the new space we are suggesting that he use as much of the same material keeping it more carefully composed for the smaller space.

33. Louise Orwig to Edward Rowan, 11/9/1935, RG 121, entry 133, box 28; Edward Rowan to Louise Orwig, 11/13/1935, ibid. 


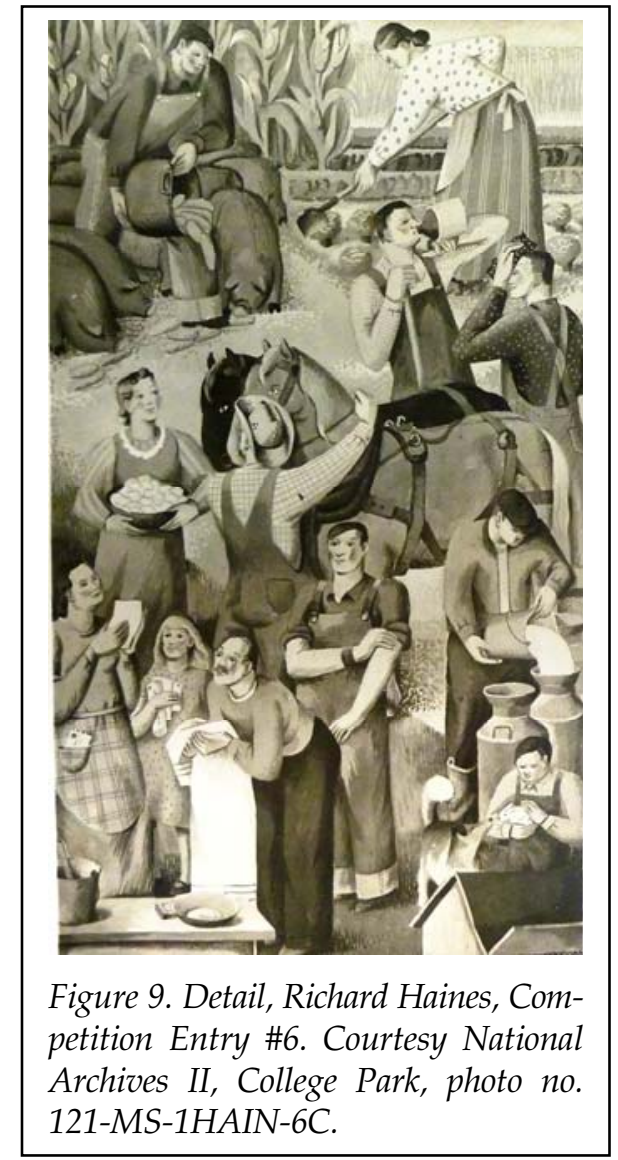

Houser's winning design, Rowan explained, was "better suited to the mural problem" of the Ames Post Office in scale and color. In addition, it presented an "unusually intelligent conception tying together the ancient Mayan and American corn agriculture." For its simpler composition and innovative subject matter, he concluded, Houser's mural sketch "seemed to us the only design in the competition with a really significant theme." ${ }^{34}$

IT IS UNCLEAR exactly what Rowan meant by this final statement, but apparently the Section recognized the greater merit of Houser's mural as history painting. Houser's conception for

34. Edward Rowan to Carl Weeks, 11/26/1935, RG 121, entry 133, box 28. 
The Evolution of Corn conforms to academic definitions of history painting in two important ways. First, Houser selected for depiction a scene from ancient history. Since its inception as a grand genre in the seventeenth century, history painting had relied heavily on figures and events from classical Greece and Rome as models for admirable actions and ideal civic traits. Houser did not choose Greek or Roman subject matter for his mural sketch, but he did stay true to the spirit of conventional history painting in his portrayal of the distant past by choosing New World equivalents. Archaeologists and scholars at that time often compared the achievements of the ancient Mayans to those of other esteemed civilizations, especially ancient Greece. Sylvanus Morley was a strong proponent of this favorable mode of assessment. Between 1922 and 1936, the archaeologist published several articles for National Geographic in which he proclaimed the Mayans "The Greeks of the New World." He also compiled evidence in support of his claim in an early report for the Carnegie Institution of Washington, stating,

[Mayan] history recorded in their hieroglyphic inscriptions covers a range of more than a thousand years; their observations in astronomy reveal a knowledge of the movements of heavenly bodies equaled by that of few peoples of antiquity; their system of chronology kept an account of elapsed time which in accuracy rivals our own; while in sculpture, painting, and architecture the Maya have been most aptly termed "The Greeks of the New World." ${ }^{35}$

Implicit in this sobriquet is the notion that the Mayans were a sophisticated, civilized, and relatively peaceful people. In keeping with such characterizations of Mayan culture, Houser in his mural sketch represents the Mayan Indian figure industriously engaged in agricultural pursuits. The muscular anatomy and graceful movements of the scantily clad Indian in his design also recalls the heroic nudity often employed in conventional history paintings to denote moral purity. In this way, Houser's portrayal of the ancient Mayan figure and his modern counterpart, who in the final version of the mural conspicuously mir-

35. Sylvanus Griswold Morley, "The Foremost Intellectual Achievement of Ancient America," National Geographic 41 (February 1922), 109-31; idem, "Archaeological Research at the Ruins of Chichen Itza," in Reports upon the Present Condition and Future Needs of the Science of Archaeology 61-97 (Washington, DC, 1913), 63. 
rors the Mayan in both action and pose, fulfills the traditional aim of public art by stirring viewers' imaginations and by providing models of dignity and civic virtue for them to emulate.

Houser subscribed to a particular Native American mythos in which indigenous cultures spanning the entire continent shared a singular, distinct history and culture. He did not distinguish among various American Indian groups. Instead, he believed that the Mayans were the "fountain head" of all other Native American cultures: "The other Indians were to the Mayas much as the out-of-the-way provinces of Rome were to the Greeks." ${ }^{36}$ Houser was not alone in this idea. The catalog for the exhibition Indian Art of the United States informed visitors that traditional American Indian art "can best be considered as folk art" because indigenous culture had reached its peak in ancient Mexico and in the Andes. ${ }^{37}$ In that context, Houser's inclusion of a Mayan figure rather than a Plains Indian in his mural design would not only be an acceptable artistic choice, but a more respectable one. Indeed, the Ames Daily Tribune and Times stressed the antiquity and cultural prestige of ancient Mexico, explaining that Houser's mural depicted "corn cultivation as practiced by the Maya Indian, which marks the very beginning, so far as is known, of American civilization." ${ }^{38}$

Houser sought in his mural design to accomplish the didactic mission of history painting by teaching viewers about ancient America. Herbert Spinden, the curator of ethnology at the Brooklyn Museum, shared Houser's belief in the educational value of pre-Columbian materials. During the Great Depression, Spinden developed an educational outreach program that employed the museum's American Indian collection as a didactic tool "for the socialization and assimilation" of the influx of Eastern European immigrants to his city. ${ }^{39}$

36. Lowell Houser to Mickey, 9/7/1930, quoted in Delpar, The Enormous Vogue of Things Mexican, 193. See also Meixner, "Houser's Poetic Glass Mural."

37. Frederic H. Douglas and René d'Harnoncourt, Indian Art of the United States (New York, 1941), 11.

38. Ames Daily Tribune and Times, 4/20/1938.

39. Barbara Braun, Pre-Columbian Art and the Post-Columbian World (New York, 1993), 42. 
To enhance the educational value of his mural design, Houser toiled to incorporate "authentic" descriptive details in his composition. In the field of history painting, the accurate portrayal of costume and accoutrements lent legitimacy to the overall scene. The perceived "truthfulness" of a painting was fundamental to its success in cultivating refined behavior and artistic taste in the public, since viewers would only be inspired to greater civic virtue if they believed in the two-dimensional models before them. Additionally, the general art-viewing public of the 1930s exhibited a marked preference for naturalism and, by extension, absolute truth of representation. As art historian Virginia Mecklenburg remarked in her insightful analysis of New Deal art patronage, "Most communities demanded unflinching accuracy in their art, and several cities refused to accept murals that violated this precept." ${ }^{40}$

Mexican antiquity at that time still remained a relatively specialized field of knowledge, the purview of historians and archaeologists. Houser, who had seen ancient Mayan art firsthand during his tenure with the Carnegie Institution of Washington at Chichen Itza, was uniquely qualified to offer insight on this impressive if mysterious ancient civilization, and his experience certainly aided him in his endeavor to include "authentic" details. Frank J. Linn, a student at Iowa State University who served as the model for both the farmer and the Mayan Indian figures in the Ames mural, recalled that Houser would relate "his experiences painting Mayan temples in Yucatan" as he worked. ${ }^{41}$ Not only did the artist have ample firsthand experience with Mayan artwork during the expedition, but he had also studied Aztec sculpture at museums in Mexico City.

Houser also made a point of modeling the seated maize god at the center of his composition upon an archaeological line drawing. Specifically, Houser referred to an illustration showing "the principle gods of the ancient Maya" in an article his former

40. Virginia Mecklenburg, The Public as Patron: A History of the Treasury Department Mural Program (College Park, MD, 1979).

41. Ames Daily Tribune, 5/11/1985. Edward Rowan also emphasized truth of descriptive detail in public art when, in a letter to Ames competition participant R. E. Beard, he extolled Houser's mural design for its portrait representation of Frank J. Linn, "a graduate of Ames [Iowa State College]," as the modern farmer. 


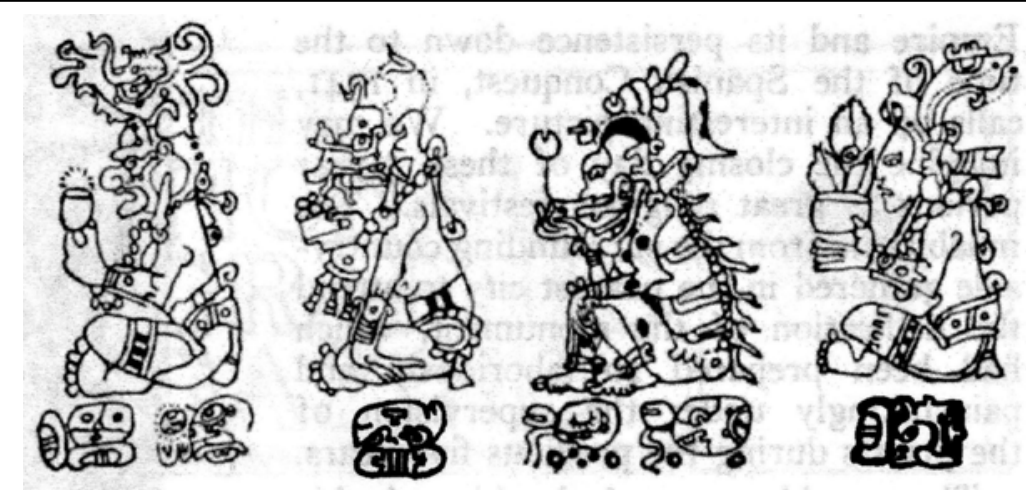

THE PRINCIPAL GODS OF THE ANCIENT MAYA

There were not less than twelve major deities in the Maya Pantheon. The four most important are represented here with their name hieroglyphs below them. From left to right they are: Itzamna, the Mayan Jupiter and the Father of Mankind; Kukulcan, the Feathered Serpent, Culture Hero of the Itza nation: Ahpuch, the Lord of Death (note the fleshless lower jaw used in the head numbers for 10, 14, 15, 16, 17, 18, and 19); and $Y$ un Kax, Lord of the Harvest, his head-dress representing a conventionalized ear of corn

Figure 10. Illustration of the Mayan Corn God (far right). Published in Sylvanus Griswold Morley, "The Foremost Intellectual Achievement of Ancient America," National Geographic 41 (February 1922), 127.

archaeological supervisor, Sylvanus Morley, had written for $\mathrm{Na}$ tional Geographic (fig. 10). Houser's deity bears a striking resemblance to "Yum Kax, Lord of the Harvest," who is shown at the far right of the magazine illustration. Shown in profile, the Mayan deity is seated cross-legged and holds before his chest a small, round pot from which emerges the curled leaves of a young maize plant and an oversized seed kernel, the Mayan glyph for corn. The pre-Columbian god wears large jade earspools, a beaded jade necklace, and an elaborate headdress representing "a conventionalized ear of corn," all symbols of his divine status. The deity in both images exhibits a sharply sloped forehead, pointy chin, decorative wrist cuffs and an elaborately woven skirt. Houser was so precise in his quotation of the illustration that he reproduced even the claw-like thumbnail, rounded toes, and pronounced arch of the foot for the figure in his competition mural sketch. 
While preparing the final version of his mural for installation, Houser continued to modify his original design with additional references to specific Mayan and Aztec objects. According to the Ames Daily Tribune and Times, the pre-Columbian deity in the sky was actually a conflation of two monuments. "The face and square of the ancient sun, from one of the earliest known Guatemalan steles or square monuments, are imposed on the round sun shield of the Aztecs, the later people who conquered the Mayas." ${ }^{42}$

HOUSER'S MURAL SKETCH further succeeded in the Ames mural competition because of its skillful handling of color and scale. While the artist remained faithful to the major tenets of history painting as a genre, he deviated from the European academic model with regard to technical concerns such as composition, drawing, and color. In both form and style, Houser attempted to transcend European artistic conventions by employing modern compositional techniques from the Mexican mural movement.

Houser's extended working relationship with Jean Charlot at Chichen Itza established a lifelong friendship, and the two artists sustained a keen interest in each other's work throughout their careers. In early May 1937 Charlot traveled to Iowa to visit Houser, who at that time was reworking his design for the Ames Post Office mural. ${ }^{43}$ Charlot's philosophy about mural design must have influenced Houser's thinking. In an essay for American Scholar, Charlot exhorted artists to adopt a particular "mural style" in response to the architectural and optical challenges of that medium. A mural artist must take into consideration not only the obvious architectural limitations of a building, such as doors and windows, he argued, but acknowledge that "there is a fitness when the space enclosed between the walls of a given room opens into a painted space similarly limited and ordered." Charlot also advised artists to employ earth tones, simple modeling, and geometrically rendered figures on a he-

42. Ames Daily Tribune and Times, 4/20/1938.

43. Jean Charlot to Zohmah Day (Charlot), 5/10/1937, Jean Charlot Collection, University of Hawaii at Manoa Libraries, Honolulu, Hawaii. 
roic scale to ensure legibility in their mural paintings "from both centered and lateral vision. ${ }^{\prime 44}$

While working to transform his mural sketch into a final painting, Houser, in his correspondence with Superintendent Rowan, exhibited a deliberate sensitivity to optical and architectural considerations, suggesting an intimate familiarity with Charlot's tenets on mural painting. In 1936 Houser faced the arduous task of modifying his competition design to accommodate a set of bulletin boards installed next to the postmaster's door. Houser had made full use of the vertical wall space flanking the door frame in his preliminary sketch. Recognizing the challenge, the artist first appealed to the Section to intervene on his behalf in hopes that the space might be restored to its original configuration. The Section contacted the Ames postmaster regarding the matter but concluded that Houser had no choice but to redesign his composition to suit the wall's new, limited dimensions. Houser was understandably disappointed, because his winning design now required significant revisions. ${ }^{45}$

Over the next 16 months, Houser merged the three panels of his preliminary design into a single, horizontal frieze-like composition. In a letter to Superintendent Rowan explaining the redesigned mural, Houser related how he "could find no way of using the wagon in the same scale as the man, except by reducing the whole thing to a size that would not show on the wall." Heeding Charlot's call for legibility in mural painting, he "dropped it." ${ }^{46} \mathrm{He}$ also divided the elements of the central "hieroglyph" to form the basis for more elaborate scenery on each half on the mural, and he added new iconographic elements and decorative details, including the Mayan rain deity, the scientific water molecule, and ticker tape. Finally, he in-

44. Jean Charlot, "Public Speaking in Paint," American Scholar 10 (1941), 455-68. Although Charlot's article on mural painting did not appear in print until 1941, six years after Houser conceived his design for the Ames mural competition, the two artists maintained a lasting friendship. A testament to their enduring mutual admiration is Charlot's decision to include a reproduction of Houser's The Evolution of Corn in his 1945 article, "Murals for Tomorrow," for the journal Art News.

45. Correspondence between Lowell House and Edward Rowan, SeptemberDecember 1936, RG 121, entry 133, box 28.

46. Houser to Rowan, 1/2/1937, RG 121, entry 133, box 28. 
verted the modern Iowa farmer to face toward the center of the composition, and he reconceived the figure's pose to create greater balance and symmetry.

Houser also had success in harmonizing the updated mural design with the overall structure of the building. Recalling Charlot's pronouncement that the most successful murals are those that are "similarly limited and ordered" to their surroundings, Houser reported to Rowan that the rectangular elements of his updated composition mimicked the architectural design of the post office. Even so, he fretted about how best to harmonize his mural in the new space. In the months preceding the mural's installation, he composed a series of letters to Rowan expressing anxiety over the paint colors chosen for the post office's interior walls, explaining, "When I designed the colors of the painting I had in mind the off white tone of the plaster as it then appeared." Houser, who had followed Charlot's endorsement of earth tones, feared that the proposed color for the lobby would not coordinate with his painting. "I hope that the color chosen for the paint job will not depart too much," he added. ${ }^{47}$

Finally, Charlot's other writings, both published and unpublished, held considerable importance to Houser with regard to establishing his place in history. Charlot identified ancient Mayan mural paintings as belonging to a "truly indigenous tradition" whose legacy might easily be seen in the modern mural decorations of Mexico and the United States. ${ }^{48}$ Later, he related this notion of a continuous mural tradition to his personal experience, reflecting that by digging "at the roots of Mexican art" at Chichen Itza, he had helped it in developing "some of its newest buds." ${ }^{\prime 9}$ In this line of reasoning, the Mayan figure in Houser's Ames mural competition entry becomes self-referential, a clever

47. Houser to Rowan, 7/23/1936, RG 121, entry 133, box 28; Houser to Rowan, 10/18/1937, ibid.; Houser to Rowan, 2/2/1938, ibid.; Rowan to Houser, 2/9/ 1938; Rowan, Memorandum to Supervising Architect, 2/18/1938, ibid.

48. Jean Charlot, "Mayan Art," Magazine of Art, July 1935; idem, "A TwelfthCentury Mayan Mural," Magazine of Art, November 1938, both reprinted in An Artist on Art: Collected Essays of Jean Charlot, vol. 2 (Honolulu, 1972).

49. Jean Charlot, unpublished manuscript pages (505-6) of The Mexican Mural Renaissance, 1920-1925 (New Haven, CT, 1963), Jean Charlot Collection, University of Hawaii at Manoa Libraries, Honolulu, Hawaii; quoted in Delpar, The Enormous Vogue of Things Mexican, 103. 
means by which the artist may both participate in and pay homage to this distinguished artistic lineage.

IN LATE APRIL 1938, Lowell Houser witnessed the installation of his completed mural The Evolution of Corn (1938) above the postmaster's door at the central post office in Ames, Iowa. The hanging of this large canvas marked for the artist the completion of a multiyear contract with the U.S. Treasury Department's Section of Painting and Sculpture. Measuring roughly $18^{\prime} \times 6^{\prime}$, Houser's mural juxtaposes two figural scenes, one ancient and one modern, depicting the cultivation of corn (fig. 7).

The left section shows a tawny, muscular man bending at the waist to plunge a wooden staff tipped with an obsidian blade into the earth. Fully nude with the exception of a white loincloth, a cylindrical cloth headdress, and simple thong sandals, the man strides forward in a wide-legged stance that accentuates his well-defined muscles and toned body. Lush vertical shoots of green cornstalks surround him, indicating that his physical labor is directed at tending the maize crop. Behind him, at the base of a mature tree, is a carved stone deity representing the maize god of the ancient Mayan civilization. A large sun disc bearing the frightful visage of the Mayan rain god dominates the sky above a distant white stepped pyramid, while gray storm clouds composed of jagged lightning bolts, a sinuous serpent, and a second, ghostly image of the rain god dispense dense streams of precipitation upon the maize below.

In the right half of the composition, a modern Iowa farmer dressed in sturdy denim overalls, a long-sleeved, button-up shirt, work gloves, boots, and a brimmed denim cap mirrors the wide stance and bent posture of his Mayan counterpart. Surrounded by golden stalks and dry, bristling leaves of mature corn plants, the fair-skinned figure leans forward with a sharp-bladed sickle to manually harvest ripe ears of corn. Cascading strips of tickertape mimic the jungle foliage on the left, while a modern microscope takes the place of the antique stone deity. Water molecules in the form of white arrows evaporate from the distant Ames skyline. Above, a scientifically rendered sun inscribed with statistics such as the sun's surface temperature fills much of the sky, while a thin strip of clouds containing scientific instruments 
spews gray sheets of rain upon the fields below. Houser's stated goal for this section was "to make a sort of modern hieroglyph of the present [scientific] explanation of the sun and rain" to complement his portrayal of Mayan cosmology on the left. ${ }^{50}$ The central panel dividing these two scenes depicts a monumental ear of corn, a transparent kernel sprouting roots, and a superimposed cornstalk, encapsulating the full growth cycle of the Iowa crop, from seed embryo to ripened ear, against a vibrant red background.

According to the Ames Daily Tribune and Times, "a stream of curious people" visited the post office for the express purpose of viewing the mural. Reactions were favorable. Ames resident Dora Oberg, for example, called the painting "a beautiful piece of work"; C. L. Smith, an entomologist at Iowa State College, declared, "It surely is nice." Local residents praised Houser's skillful coloring and balanced composition but debated the accuracy of the modern half of the painting. Viewers puzzled over the abstracted water molecules and deplored the "unrealistic" portrayal of the modern Iowa farmer. "If that's the way you pick corn, I'd hate to live on a farm," announced S. A. Nichols, a local Ames resident who felt that Houser had represented the harvesting farmer in an exaggerated pose. ${ }^{51}$ No one was quoted as questioning the appropriateness of Houser's decision to include a Mayan Indian in the mural rather than a member of an indigenous group with historical ties to Iowa.

In the Ames mural competition, Lowell Houser successfully capitalized on the widespread cultural interest in Mexico and demonstrated in his mural design a technical and thematic expertise derived from firsthand knowledge of Mexico's modern art and pre-Columbian civilizations. By depicting a scene of American antiquity and by skillfully executing color and scale, Houser successfully crafted a nationalistic history painting that not only asserts a continuity of agricultural practices from the ancient Mayans to the present day but also positions the artist as the cultural inheritor of a long-established Native American artistic tradition. In so doing, Houser conceived of a mural de-

50. Houser to Rowan, 1/2/1937, RG 121, entry 133, box 28.

51. Ames Daily Tribune and Times, 4/20/1938. 
sign that Superintendent Edward Rowan deemed "one of the best, most thoughtful and hence significant, sketches that has ever come in any competition." ${ }^{52}$

52. Edward Rowan to Louise Orwig, 3/23/1936, RG 121, entry 133, box 28. 